\title{
Vandens motyvas Liūnės Sutemos ir Astridos Ivaskos poezijoje
}

\author{
INGA STEPUKONIENĖ \\ Vytauto Didžiojo universitetas, Letonikos centras, V. Putvinskio g. 23-219, LT-44243 Kaunas \\ El. paštas i.stepukoniene@hmf.vdu.lt
}

\begin{abstract}
Straipsnyje pasitelkus fenomenologinès analizès principus siekiama apžvelgti vandens motyvo svarbą dviejų baltų tautų poečiu - Liūnès Sutemos ir Astridos Ivaskos kūryboje. Reikšmingas Liūnès Sutemos ir Astridos Ivaskos poetinio pasaulèvaizdžio elementas yra vanduo, savitai ženklinantis pasaulio ritmus ir žmogaus egzistenciją, glaudžiai susijęs su asmenybès saviidentifikacija.

Liūnès Sutemos ir Astridos Ivaskos poezijoje vandens stichija dažniausia iprasminama lietaus, sniego, ledo, ežero, jūros struktūra, kuria liudijama stipri gyvenimo manifestacija, viename lygmenyje simboliškai susiejant realybę ir iliuziją, realų ir anapusinị pasaulį.

Vanduo Liūnès Sutemos ir Astridos Ivaskos poezijoje yra ir mirties, ir gyvybès simbolis. Poečių kūrybą artina ryškios individo pastangos išsaugoti savą dvasinị pasaulį, savą kultūrinị "ego" - etninę atmintị subrandinusị gimtosios aplinkos, kalbos, žmonių santykių lauką; jūros banga, lietus, sniegas, lašas - dažniausios vandens formos, eileraščio poetinèje erdvejje įprasminančios šias gyvybès išlaikymo, sielos atgijimo, pabudimo semas. Liūnès Sutemos ir Astridos Ivaskos kūrybą artina ir saviidentifikacijos paieškos: pasiaukojančios, atnašaujančios moters savastis.

Darbo metodai: analitinis interpretacinis, aprašomasis, fenomenologinis, lyginamasis.
\end{abstract}

Raktažodžiai: Liūnès Sutemos poezija, Astridos Ivaskos poezija, vandens motyvas, poetinè refleksija

\section{IVADAS}

Liūnė Sutema ir Astrida Ivaska - neabejotinai vienos savičiausių baltų tautų literatūros kūrèjų. Abiejų poetinị pasaulèvaizdị formavo panašios biografinès slinktys, laikotarpio istorinè, politinè ir kultūrinè situacija, kartos pasaulejjauta, dèmesys baltų istorinei ir kultūrinei praeičiai. Abi gimusios bemaž vienu laiku - Liūnè Sutema - 1927 m., Astrida Ivaska - 1926 m., brendusios miesto kultūros aplinkoje: Liūnès Sutemos tèvas, geležinkelietis, nuolat kèlèsi iš vieno Lietuvos miesto ị kitą, Astrida Ivaska gimè ir augo sostinèje Rygoje. Liūnė Sutema ir Astrida Ivaska - daugiakultūrès asmenybès, kurių dvasinis formavimasis vyko keliakalbiame kultūriniame kontekste: Liūnès Sutemos mama - latvė, senelè - vokieté, Astridos Ivaskos šeimoje buvo kalbama keliomis kalbomis, o jos vyru vèliau tapo estas Ivaras Ivaskas. Ir vienai, ir kitai nuo vaikystės tampa artimos Vakarų 
kultūrinès realijos: literatūra, menas, kontaktai su Vakaruose studijas baigusiais žmonèmis. Didelę ịtaką poečių dvasiniam ir kūrybiniam formavimuisi turèjo nepriklausomų Lietuvos ir Latvijos šalių kultūra, aktyvus to meto tautų dvasinis gyvenimas ir ypač - lietuvių ir latvių tarpusavio santykiai, atsiveriantys iš supančios kaimyniškos gyvenimo paribyje aplinkos, giminiškos bendrystès ir ịvairių kultūrinių (literatūra, muzika, dailè) ryšių. Ir vienai, ir kitai kūrèjai nuo mažumès buvo artimas ir brangus baltų kultūros pasaulis, mito, tautosakos formomis giliai ịsiskverbęs ị sąmonę ir vèliau plačiai išsiskleidęs poezijoje.

Sovietine okupacija abiejų šeimas priverčia trauktis ị Vakarus. Emigracijos sąlygota būtis, paženklinta didžiulio tèvynės ilgesio, prarastos valstybės, namų, artimųjų išgyvenimų, itin suartino abiejų poečių kūrybą tematiniais ir probleminiais aspektais. Jų lyrikoje iškyla iš namų išginto lyrinio „aš“ praeities reminiscencijos, negatyvi emigranto dabartis: asmenybės skilimas, slèpimasis po kaukèmis, glaudaus žmogaus ir pasaulio ryšio praradimas, visa tai perteikiant ramia, sutaurinta emocija. Pasak R. Šilbajorio, Liūnès Sutemos poezija, kurioje tautos atsakomybės pajautimas iškilęs iki tragiškos aukštumos, „gaji, neprijaukinama, skaudi, giliai suleido savo atkaklias šaknis ị išeivijos kultūrinès sąmonès klodą ir liks tenai, gal paskutinis gyvas ženklas, kai toji sąmonè jau bus sausa ir kieta, kaip badmečio molis“ $[4,163]$.

Astrida Ivaska - taip pat „išeivijos poetè, kurios kūryboje siekiama ne šokiruoti, bet praverti jausminį žmogaus pasaulį, jo gelmę, ì pirmą planą iškeliant pojūčių tikrovę. A. Ivaskos kūryboje pastebimas latvių lyrikai būdingas glaudus ryšys su gyvąja gamta; gamtos pasaulio paslaptys, poetès bandymas priarteti prie visko, kas natūralu, ir plaukia iš gamtos pasaulio, išskiria jos kūrybą visame latvių literatūros kontekste“ $[7,85]$. Jos poetinis žodis - visuomet siekiantis gilios esmès, atspindintis gamtos daugiareikšmiškumą, platybę, jos galią. Anot D. Lūsès, būtent gamta - dèmesys žolei, vandens srovenimui, voratinklio siūleliui - ir lyrinio „aš“ jausmai, santūriai, tarsi per atstumą, išsakant savo skausmą, ir sugebejimas tai išreikšti latvių kalba daro A. Ivaskos poeziją nepaprastai latvišką $[6,24]$. Latviškumo, nacionalumo kodas jos kūryboje labai ryškus: net ir svetimo pasaulio vaizduose jaučiama Latvija. Dèmesys gamtai, jos stebejjimas atsispindi ir poetės rinkinių pavadinimuose: „Ežero krikštynos“ (Ezera kristības, 1966), „Žiemos teismas“ (Ziemas tiesa, 1968), „Žingsnis i ǐilus“ (Solis silos, 1973), „Šviesa sužeide்“ (Gaisma ievainoja, 1982). Kaip ir Liūnès Sutemos poezijoje, A. Ivaskos eilèraščiai siejasi, pratęsia vienas kitą, jungiami ị ciklus.

Reikšmingas abiejų poečių poetinio pasaulèvaizdžio elementas yra vanduo, savitai ženklinantis pasaulio ritmus ir žmogaus egzistenciją, glaudžiai susijęs su asmenybès saviidentifikacija. Tad šio straipsnio tikslas - apžvelgti vandens semantiką ir šio motyvo raišką Liūnès Sutemos ir Astridos Ivaskos poezijoje.

Anot prancūzų fenomenologo G. Bachelard’o, vanduo poezijoje yra glaudžiai susijęs su kūrybinès vaizduotès galiomis; iš visų keturių pirminių elementų (žemė, oras, ugnis, vanduo) jis labiausiai inspiruoja svajones, tad literatūros kūrejo sąmoneje ar pasąmonèje iškylantys vaizdiniai yra svajonių išraiška. Poetinès vandens figūros (bangos, purslai, kriauklès, jūros ošimas, vandenynas) simbolizuoja pasąmonès troškimus; nuolatinè gyvybinio gamtos ciklo kaita vaizdžiai įkūnijama kylančių ir dūžtančių bangų metaforomis; balta gulbè yra moters projekcija poeto sąmoneje, tekantis dumblas, purvo marios, potvynis simbolizuoja nelaimę, o vandens ir žemės jungtis, vandens paukščiu skrydis danguje simboliškai atnaujina pasaulèkūrą, ženklina kosmogonijos aktą, pasipriešinimą blogiui; lietus - apsivalymo aktą, sniegas, šerkšnas, ledas - dvasinị sąstingi. Taigi vandens poetinių figūrų gausa, jo regimybių ìvairovė yra didžiulè. Dar daugiau - kiekviena 
šios gamtos stichijos forma pasižymi savo unikaliomis kokybinėmis skirtybėmis: garsiniu skambesiu, spalva, kvapu. Vanduo, pasak G. Bachelard'o, „pasirodo kaip totali bùtybė: jis turi kūną, sielą, balsą. Todèl daugiau nei galbūt koks kitas elementas vanduo yra pilna poetinè realybė.“ „Poetui vanduo turi įkvèpti naują priedermę; elemento vientisumo priedermę. Be šio vientisumo materiali vaizduotè nèra patenkinama, o formalios vaizduotès nepakanka susieti skirtingas savybes.“ Tada kūriniui „stinga gyvenimo, nes jam trūksta substancijos" $[1,132]$.

Kita svarbi G. Bachelard’o įžvalga - vaizduotė nèra sugebejjimas kurti realybės vaizdus; ji yra gebejjimas kurti realybę peraugančius vaizdus, išrasti „kažką daugiau negu žodžiai ir dramos“, „atverti viską naujai reginčias akis“ $[1,133]$. Ji mus žadina, kartu ,,išsaugodama buvusių sapnų prisiminimą“, brangiausius nutikimus, „ištikusius anksčiau nei juos pastebejo siela“ (D’Annunzio); tad „kai imame atverti akis regimybei, esame jau seniai susilietę su neregimu“ $[1,133]$. Tai komentuodamas G. Bachelard’as cituoja E. A. Po: „Kalną mylime ne todèl, kad jis žalias, o Jūrą ne todèl, kad žydra, netgi ir tuomet, kai taip aiškiname savo susižavejjimą, o todèl, kad kažkas mumyse, mūsų pasąmonès prisiminimuose yra i̊sikūniję žydroje jūroje ar žaliame kalne. Ir tas mūsų nesąmoningų prisiminimų kažkas visada ir visur prasideda mūsų vaikystės meilèmis, kurios pirmučiausia buvo nukreiptos ì būtybę-prieglobstị, būtybę-peną" $[1,226]$. Kitaip sakant, svajonès yra inspiruojamos šviesių prisiminimų ilgesio.

\section{VANDENS STICHIJOS REPREZENTACIJA POEČIŲ LYRIKOJE}

Kaip minèta, Liūnès Sutemos ir A. Ivaskos eilèraščius vienija panaši lyrinio vyksmo erdvè, moterų žvilgsnis ị pasauli, poetinio „aš“ laikysena, dèmesys gamtos realybei. Tarp gamtos reiškinių vaizdinių poečių lyrikoje ryškiai iškyla sudètinga ir daugiasluoksnè vandens stichija ir ịvairios jos moduliacijos, svarbios kūrejjų meniniam pasaulèvaizdžiui. Vandens reikšmę jų poetiniam mąstymui liudija jau pats Liūnès Sutemos pseudonimas, kurio pirmasis sandas ženklina pelkès, liūno prasmes. A. Ivaskos poezijoje yra reikšmingi visi keturi mitiniai elementai (ugnis, vanduo, žemè, oras), tačiau vanduo lieka svarbiausias, savo galia gerokai praaugantis ịprastinio ịvaizdžio rèmus. Vanduo viena ar kita forma minimas beveik kiekviename A. Ivaskos eilèraštyje ir reiškia skirtingus potyrius bei išgyvenimus; pasak G. Bachelard’o, jis yra ir poetès peizažų ornamentas, ir tikroji jos apmąstymų substancija. Šią ịvaizdžio dominantę išryškina ir jos eilèraščių rinkinio pavadinimas „Skraidantis ežeras“. Abiejų poečiu kūryboje egzistuoja daugybė skirtingų šio įvaizdžio ir motyvo interpretacijų, tačiau yra ir jas vienijantis konceptualus pagrindas.

Liūnès Sutemos ir A. Ivaskos poezijoje vandens stichija dažniausia îprasminama lietaus, sniego, ledo, ežero simboline struktūra, kuria liudijama stipri gyvenimo manifestacija, viename lygmenyje simboliškai susiejant realybę ir iliuziją, realų ir anapusinị pasaulį. Vandens - lietaus, drègmès, ledo, sniego, ežero, upès - vaizdiniai tarpusavyje sąveikauja ir papildo vienas kitą. Jų skirtinga semantika, savita poetinè raiška, tačiau poečių kūryboje, beveik visuomet ịbūtindami praeities ženklus (mitinius ar istorinius) ir kitą - sapno / fantazijos pasaulí, jie realizuoja giliai pasąmonèje glūdinčios svajonès, dažniausia besišaknijančios vaikystès ar jaunystès laike, išgyvenimą.

G. Bachelard’o teigimu, „ne realus pažinimas verčia mus aistringai mylèti realybę, o jausmas, kuris yra pagrindinè ir pirmoji vertybe்“; gamtą pradedame „,mylèti dar jos nepažinę, gerai jos nematydami, jusdami daiktams meilę, kuri kyla kitur“ $[1,225]$. Kitur - tai prigimtinès realybės laukas, apgaubiantis žmogų visomis savo šviesos galiomis, visam laikui 
įrašantis ji ̨ i individo sąmonę. Tyrèjo manymu, toks sielų jausmas gamtai yra itin tvarus, nes jo prigimtis yra sūniškas jausmas gamtai, kuri jausminiu požiūriu yra ị begalybę kylanti motinos projekcija [1,225]. Liūnès Sutemos ir A. Ivaskos, baltų poečių, išeivių iš savosios žemès, sąmonejje tokio prigimtinio lauko praradimas sublimuojasi ị ištisą nerealizuotų svajonių, dramatiškų išgyvenimų ir potyrių lauką; jame justi ši sūniška / dukteriška ištikimybe motinos gamtos / žemès / tèvynès, namų, žodžio / kalbos, tiesos / laisvės kategorijoms, kurioms suteikiama didžioji dvasinè vertè. Gili priklausomybe šio prigimtinio lauko tradicijoms, daiktams, idealams ir negalèjimas to susigrąžinti lyrinị „,aš paverčia nuo realios tikrovès atsiribojusiu svajotoju, žvelgiančiu ị pasauli ilgesio, melancholijos, ironijos žvilgsniu. Poetinio vaizdo struktūras diktuoja ịskaudinta sąmonè, neretai inversiškai dèliojanti gèrio ir blogio, grožio ir bjaurumo, vilties ir nevilties simbolines struktūras, o gilioji eilèraščio substancija teigia begalinị prigimtinio universumo ilgesị. Liūnès Sutemos ir A. Ivaskos poezijoje tokios lyrinio „aš“ situacijos dažnai atsiveria vidaus ir išorès vandenų - ežero, upès, balų, jūros - motyvu ar apmąstymu. Liūnès Sutemos poezijoje ežeras - viena būdingiausių vandens reprezentacijų - yra sietinas su ryškesniu lietuvių polinkiu vaizduoti vidaus vandenis, palyginti su latviais.

Žveris žaliom akim tyko į mano nakti,

isitempęs šuoliui - aš bijau užmigt,

kad sapne neatskristų laukinés antys,

išklykdamos mūsų burtažodi

i žveries pravertus nasrus,

tvankia drégme garuojančius,

lyg ežeras, kurio vardą seniai užmiršau,

ir bijau prisiminti, bijau,

kad sapne neatbègtu baltasis èriukas

ištroškęs, ir jo basakoje sesuo -

plečias žalios akys žveries ir mano,

nuo laukimo ir itampos.

Ko užtrunka, ko neateina broliai,

užkapoję dalgiais Žilvina,

noriu paslaptị jiems išduot -

noriu užmigt. Ne sapnuot.

(„Leliojimai“ $[4,31]$ )

Eilèraštyje ryški Liūnès Sutemos kūrybai būdinga simbolinè asociatyvi gija tarp lyrinio „aš ir vandens pasaulio. Kūrinio vaizdinèje plotmèje implikuojama sapno / grèsmès situacija leidžia pajusti disharmoniško pasaulio funkcionavimą subjekto sąmonejje, baimès būseną. Eilèraštyje vienas kitą perdengia mitiniai motyvai, kuriuose svarbi vandens mitologema (nugrimzdusio ežero, Eglès ir Žalčio, broliuko, atsigèrusio iš pèdos vandens ir virtusio ėriuku). Intensyvi vandens metaforikos kaita ženklina absoliutų egzistencinio stabilumo praradimą, suardytą pasaulio ir namų harmoniją, sujauktą gyvenimo ritmą ir tvarką, didžiulę išorinių aplinkybių įtaką subjekto vidiniam „ašc. Lyrinis „aš“ tarsi gyvena dviejuose pasauliuose: realiame ir tame, kuris atslenka su sapnais, kai aktyvią sąmonę nugali pasąmoné - giliuosiuose asmenybès dvasios kloduose glūdintys prigimtinio lauko (laukinès antys, baltasis èriukas, basakojè sesuo, Žilvinas) ir iškilusios grèsmès jam, katastrofos (žvèris, broliai su dalgiais) prisiminimai. Kaip ir kiti Liūnès Sutemos kūriniai, taip ir šis pasižymi stipriu sujaukto pasaulio pojūčiu. Vanduo jame ženklina ir gilina išdavystès, sutrūkinejjusių, grèsmingų, priešiškų žmonių santykių modelị. Šiam prasmių 
laukui priskirtinas ir dažnas Liūnès Sutemos poezijoje troškulio motyvas, tuščio ąsočio įvaizdis, giliojoje teksto struktūroje reiškiantis dvasinę tuštumą ir didžiulị svajotojo ilgesị tam, kas prarasta.

Vanduo Liūnès Sutemos poezijoje yra ir mirties, ir gyvybès simbolis. Pasak G. Bachelard'o, vanduo - vienas labiausiai žmogaus minties aukštinamų (tyrumo) objektų, lyrikoje susiejantis visus tyrumo vaizdus [1,130]. Poetès kūryboje ryškios individo pastangos, troškimas išsaugoti savą dvasinị pasaulį, savą kultūrinị „ego“ - etninę savimonę subrandinusi gimtosios aplinkos, kalbos, žmonių santykių lauką; lietus, sniegas - ryškiausios vandens formos, eilèraščio poetinèje erdveje ipprasminančios šias gyvybès išlaikymo, sielos atgijimo, pabudimo semas: „Noriu būti tau lietum ir sniegu, / kad pajègtum gyvent dar metus / savyje, kaip žiemkentis rugys“ („Prieš saulès grąžą“ [4, 47]). Tai, anot G. Bachelard'o, svajonei būdingas poreikis giliai issirèžti i gamtą, nes tik tada galima giliai svajoti $[1,139]$; tik tada gali atsiverti lyriniam „aš“ jo paties tapatybe ir dualumas, dvilypès vyriškos ir moteriškos galios, o ypač - jo realumas ir idealumas [1, 140]).

Panašiai poetiniai vaizdai jungiami ir A. Ivaskos lyrikoje. Skirtingai nei Liūnès Sutemos kūryboje, ežero, jūros refleksija poetès eilèraščiuose „išoriškai“ grindžiama harmoningu lyrinio subjekto santykiu su gamta. Pasak G. Bachelard'o, „ežeras - didžiulè rami akis. Jis sugeria visą šviesą ir iš tikrųjų visą pasaulį“; taip lyrikoje „,atkuriama begalinè matymo ir matomo kaita" $[1,145]$. Anot A. Romanovskos, ežere susipina žemé, vanduo ir oras, ir šių stichijų tarpusavio ryšys kuria gyvybę [5, 95]. Ežero vanduo A. Ivaskos poezijoje yra glaudžiai susijęs su istorine - senųjų krašto gyventojų, genties - atmintimi, žadina subjekto dvasini gyvybingumą, jo pabudimo jẻgą:

Svetima vyriška jèga

kelia mane ir sūpuoja, ir laiko,

dar savo rankose laiko.

Lybiu krantai, laikykit mane

savo žydrai žaliame vainike,

pakelkit mane,

lybiu krantai išnykę,

apdainuoti daugybę amžių <...>

Kažkur iškeliauja ir tūno

žydrai žalias kalbos spindejjimas,

žodžiu karoliukai supasi jūroj. <...>

Paleiski mane, ir aš išeinu,

nepradingsiu, aš bùsiu

mèlynu karoliuku žaliame bangų kalne,

saulès karoliuku mèlynosios bangos viršūnejj.

(„Lybių krantai“ [2, 41])

Poetiniai vaizdai eilèraštyje nušviečiami, tarsi užliejami pavasariško šviežumo nuojautų, kurias padeda pasiekti ryškūs spalvų (žydrai žalios, mėlynos, geltonos / saulès), formų (vainikas, karoliukai) ir judesio (kèlimas, sūpavimas) įspūdžiai. Kūrinyje brèžiama praeities ir dabarties erdvèlaikio opozicija, ịrèminta krantų takoskyros, semantinèje plotmeje iškelia asmenybės siekị išlaikyti savyje genties istorijos ir kultūros reikšmes; gimtosios kalbos, kaip ryškiausio tapatumo dèmens, poetinè sąsaja su gyvybinga žalia vandens spalva, tyvuliuojančiu vandenų pasauliu ženklina esminị dvasinị imperatyvą - saugoti didžiausias vertes grèsmingos galios apsuptyje („aš būsiu mèlynu karoliuku žaliame bangu 
kalne“). Ežeras, išoriškai nekintantis, savyje slepia turtingą nežinomą pasauli, paženklintą mitinio pirmapradiškumo žyme ir žadinantị gyvybę. Panirus ị ežero bangas, perkertama riba tarp žemės, žmonių ir kito - paslaptingo, žmogui nepasiekiamo pasaulio, kurio vaizdinis analogas yra dangus (sūpuoklès, pakilimas aukštai). Jeanas Cohenas eilèrašti yra apibrèžęs kaip fonosemantinę struktūrą, kuriai būdinga glaudi dermè tarp semantinio plano ir fonikos $[3,54]$. Kūrinyje ryškus vieno garso kartojimas sukuria liūliavimo / supimo ịspūdị, kelia romantinio paslaptingumo nuojautas, susiejančias simbolinius atitikmenis - vandens / dangaus erdves. Vis dèlto giliosiose teksto struktūrose vaizdą įrèminanti praradimo, netekties nuojauta (išnykę lybių krantai, išnykstanti kalba) nuskaidrina jị graudaus svajotojo liūdesio, nostalgijos gaida.

Svajotojo „ego“ bene stipriausiai veikia atmintis, leidžianti prasiskverbti iki genties, tautos dvasinių ištakų, senosios istorijos, pirmapradès gyvensenos, archajiškos kalbos. Šiame baltiškų prasmių plačiame lauke ryškią su vandenų pasauliu susijusią baltišką simboliką (vandens paukščio - tarpininko tarp dangaus ir žemès, gyvybès vandens, mitinio erdvèlaikio, mitinių būtybių ir tautosakos personažų) randame A Ivaskos eilèraščiuose „Užvadas“, „Ivarui“, „Pirmoji paroda“, „Delfai“, „Poetei Latvijoje“. Eilèraštyje „Tinklai“ svajotojas-lyrinis „aš reflektuoja savo reikšmingiausią - pradžios, t. y. gimties / kilmès, situaciją, nulemmusią jo būties modelį ir dvasinę laikyseną. Simboliškai gimties vieta lokalizuojama prie senos jūros ir senoje žemejje (mitiškumo kodas), taip apibrèžiant savo dvasinès priklausomybès ribas:

Man pasiseke gimti prie ịlankos, kur žemé sena

ir dar senesne jūra. Bangos audžia tinklus, traukia mane atgal,

i praejjusius amžius... bet gyvenimo niekas negali iš manęs atimti.

Bangos audžia tinklus, juose užkliūva putos. Supasi paukščiai.

Ar jauti naktimis, kaip sujuda gintaras jūros dugno gyslose?

Mes vaikštom laisvi su vejju. Saulè audžia tinklus nuo vieno dangaus krašto iki kito.

Man patinka kristi i juos ir suptis išskèstom rankom.

(„Tinklai“ $[2,45]$ )

Jūra yra itin dažnas ịvaizdis latvių poezijoje, kurioje ryškesnis dėmesys tenka išorès vandenims. Ji ịteisina archajiškumo paradigmą ir ịprasmina centrinị vertybių polių, kurio gyvybingumas ir teikiamas palaimos jausmas stipriai jaučiamas. Jūra - žemè - moteris implikuoja A. Ivaskos lyrikoje ryškią moteriškumo triadą, kuriai būdinga kuriamoji - vaisingumo / gimdymo / auginimo - galia. Iš čia ir simboliškas jūros / moters, audžiančios tinklus, ir juose iki dangaus besisupančios laimingos moters / žuvies / paukščio gretinimas, sukuriantis romantinị pasaulio visumos vaizdini. Moteris - trimatę visatos erdvę siejanti būtis; ji jaučia palaimą (taip realizuojama gilioji pasąmonès svajonè), būdama su savo jūra, krantais, debesimis, išgyvendama savo baltiškas šaknis ir atsiverdama šviesai. Laimès pojūtị žadina gintaras, neatmenamais laikais jūros gelmių viešpatijoje sustingęs pušies sakų lašelis, siekiantis baltų genčių priešistorę, - simbolinis amžių nesunaikinamas gyvybės pradmuo jūros vandenyse, ryškiausia šio krašto gyvastingumo manifestacija, pažadinanti genties žmogaus galias. Tai itin mėgstamas A. Ivaskos poezijos įvaizdis, glaudžiai siejamas su moters svajonių metafizika.

Anot G. Bachelard’o, viena pagrindinių vandenų poezijos temų yra atspindžiai $[1,159]$. Vanduo ir jo atributai Liūnès Sutemos lyrikoje yra poetinio „aš“ atspindys; šia prasme dualią sąmonès struktūrą ịprasmina veidrodžio, lange kabančios iškabos įvaizdžiai, ženklinantys subjekto nutolimą nuo realybės, nerealizuotą svajonę („Mano iškaboj žaibu nuvingiuoja / slidus ungurys. Aš parduodu žuvis./ Dar gyvas./ Aš sveriu ir sveriu / ežeru ir upių kvepèjimą, / žveju kantrybę/ ir peleku virpèjima sveriu -,/ karta savaitèj ir prieš didžiojo džiaugsmo šventes/ 
atgailauja mano pirkèjai - //“ [4, 32-33]). Liūnès Sutemos poetiniame pasaulèvaizdyje subjektas siejamas su žeme ir vandeniu kaip pirmapradžiais elementais - taip atsiveria gilioji mitinè svajotojo pasąmoné, archetipinè atmintis, prikelianti seniausius archetipinius vaizdinius - žuvis, liūliuojančio dumblino vandens kvapai primena pirmapradžio chaoso, pasaulèkūros - kosmogoninio mito - momentus, kurių svarbą, simbolinị būtinumą jaučia kūrèjos pasąmonè. A. Ivaskos poezijoje lyrinis „aš“ dalyvauja mitiniame kosmogonijos akte, kai iš vandens susikuria visa aplink: „...šitaip radosi vanduo. / Tačiau reikèjo vandeniui žuvu./ Ir aš i pati vidurị vandens / mečiau dar viena raudona uoga - saulę, / tegu ji tarp žuvų ir medžiu viršūniu vaikštinëja“; „Ivarui“ $[2,52])$. Eilèraštyje „Pirmoji paroda“ ryški besikuriančio pasaulio pradžia - „,nuo pédų Palangoj“, „,nuo žalčio šliūžés“, „saulès kiaušinio jūros gūžtoj”, „,nuo strèlių lediniu vandeniui mirguojant", aktualizuojamos svarbiausios baltiškos kosmogonijos mitologemos (kiaušinis, lizdas vidury vandens). Šalia atgimimo motyvų A. Ivaskos eilèraščiuose jaučiamas ir susvetimejjimas, atsiskyrimas (pajūrio krante ịšalusios pẻdos), Liūnès Sutemos poezijoje mirtis ar mirties grèsmė metaforiškai suvokiama kaip laisvès prarastis (užšalęs ežeras, apledèjusios medžių šakos, liulančios klampios pelkès). Tad abiejų poečių kūryboje vandens motyvas atsiveria artimomis prasmėmis, kyla iš panašių pasąmonės impulsų, impresijų, atveria artimas gyvenimo situacijas, eilèraščiuose ịgydamas savito skambesio ir daugiareikšmiškumo.

Ir A. Ivaskos, ir Liūnès Sutemos kūryboje vanduo turi glaudų ryši su namais. Namai jų lyrikoje - ypatingos reikšmės kategorija, tačiau aplyti, gaubiami pilkos lietaus miglos, tamsių debesų. Taip tarsi realizuojama G. Bachelard’o apibrèžta simbolinè sunkaus vandens kategorija, „simbolizuojanti ypatingą gyvenimą, kurị traukia ypatinga mirtis“ [1, 160]. A. Ivaskos eilèraštyje „Audèjos namai“ smulkus lietus paverčia pasauli graudžiai ilgesingu rudeniniu paveikslu, tarsi užgniaužia jo gyvybę, išryškindamas neišsipildžiusių svajonių ir prarasties atmosferą:

Lietaus šaudyklè audžia

rasotą rudenio skarą.

Ak, vieniši namai audejos

pakraštyje didžiulio šilo.

Tavo lininè staltiesé yra vési ir kvepia vandeniu.

Asiūkliai ilgai joje gyvens ir vilkdalgiai.

\section{Šiandiena oras dūmo skonio.}

Takus tavuosius greitai jau sniegas užaus.

$$
\text { („Audèjos namai“ }[2,48] \text { ) }
$$

Eilèrašti formuoja dvisluoksnè semantika - dabarties ir praeities reminiscencijos. Rudeniniam lietui lyjant poetès lyrinis „aš prisimena savo gyvenimą, buities erdvę, kuriai suteikiama ypatinga estetinė vertè. Buitinis praeities kasdienybès laukas suvokiamas kaip savos, etninès, kultūros dalis, paprasta ir harmoninga, atsiverianti gilesne dvasine patirtimi. Skara, staltiesė yra atributai, kuriantys šių namų - moters manifestacijos erdvės - jaukumą, šilumą. Pasak A. Romanovskos, toks suromantintas ryšys su praeitimi yra viena seniausių tradicinių vandens stichijos simbolinių reikšmių $[5,95]$. Tačiau lietus A. Ivaskos kūryboje neigyja simbolinès apvalymo funkcijos, o visa apgaubia dvasinès pilkumos, graudaus liūdesio, praradimo nostalgijos gaida. Eilèraščio vaizdinejje plotmèje ryškios namų - sakralaus būties lauko - mirties nuojautos, suponuojančios žlugusio gyvenimo įspūdị. Todèl pilkuma, pilka lietaus spalva ir A. Ivaskos, ir Liūnès Sutemos kūryboje ženklina dingusio, jau svajonèje esančio pasaulio / gyvenimo kontempliavimą. 
Lietus - viena būdingiausių vandens stichijos reprezentacijų A. Ivaskos lyrikoje. Jis, kaip ir vejjas, kūrẻjos meninès vaizduotès struktūroje visuomet sietinas su neišsipildžiusiais lūkesčiais, nerealizuotų troškimų siekiamybe. Lietus pažadina veržlumą, tačiau ịkūnija ir netikrumą, nestabilumą:

Statysim namus iš vejjo, kurie supsis guobos šakose,

Statysim iš vejo namus,

iš lietaus, kuris matuoja atstuma tarp debesų ir žemès,

iš lietaus,

iš parudavusių lapu statysim namus

ir pavadinsim savo vardu.

(„Šauksime“ $[2,47]$ )

Gamtos atspindžiai - lietaus, vejjo, tuščių guobos šakų ir parudavusių lapų, fiksuojami poetinio vaizdo centre, naikina, pasak G. Bachelard'o, „laimingų spalvų svajonę“ $[1,168]$ ir atskleidžia žmogiško skausmo naštą. Taip metaforizuojamas išgintojo iš savo žemès gyvenimas - klajoklio, benamio, turinčio tik laikinus namus ir vienintelị imperatyvą - išsaugoti savyje visa, kas siejasi su gimtojo krašto kultūra. Liūnès Sutemos lyrikoje tai yra dvasinis sąstingis, eilèraščiuose reflektuojamas kaip kelione - bridimas per liūną, lietų (eilèraščių ciklas „Pirmoji kelionë“, „Antroji kelionë“). Liūnas - pavojinga žengti vieta („Aš einu ir einu, / lyg per liūną / klimpsta kojos ị samanas. / Aš nešu. Ař turiu nunešti / ant smilgų kvepiančias žemuoges / savo vaikui -, kad jisai nepradètu ilgètis / nepažistamo krašto mišku -“ („Pirmoji kelione““ $[4,39]$ ). Jei A. Ivaskos poezijoje lietus yra smulkus, pilkas ir tylus, tai Liūnès Sutemos - agresyvus, nevaldomas, nesulaikomas, savo stipria jèga užtvindantis ir užvaldantis pasaulị, neatpažistamai pakeičiantis jo kontūrus, darantis jị svetimą: mieste nuo kelrodžių ima lašèti raudonos žvaigždès, ant motinos namo durų spindi naujas užraktas-pjautuvas („Antroji kelione“), "gatvés neturi vardü“, todèl i jas neįmanoma sugrịžti. Gamta tarsi sukaustyta; stiprèja pojūtis, jog šio lietaus negalima nei sustabdyti, nei atšaukti - tai iš esmès visatą keičianti galia, sustingdanti ir žmogaus valią. Todèl eilèraščiuose ịsigali neviltis, suvokimas, kad viskas iš ankstesnio gyvenimo amžinai prarasta:

Ǎ̌ atëjau dar nešinas senuoju raktu,

apvaliu, žalvariniu raktu -

Lyja ir lyja, ir kyla

malūno tvenkiny tamsus vanduo.

Didžioji žuvis, išnirus paviršiun,

laukia grobio -

tebus jos alkis pasotintas

žalvariniu raktu -

dabar nei aš, nei motina,

tikrai nebeturim namu -

$$
\text { („Antroji kelioné“ }[4,40] \text { ) }
$$

Tamsus vanduo - siaučiančio blogio metafora Liūnès Sutemos kūryboje; pasak G. Bachelard’o, tai „žiaurus vanduo“, kryptingas inniršio, kurstymo galios, brutalumo reflektavimas [1,266]. Patekęs ỉ lietaus plūsmą, žmogus priverstas jam pasiduoti, paklusti visa valdančiai vandens stichijai; lietus apgaubia, uždengia procesijų vèliavų šilkuose Dangaus Émimo Dieną motinos bruožus, kuri, likusi blogio erdveje, praranda gyvybę. Taip kuriamas poetinis bevardès žemés vaizdinis laukas, kurị papildo ir vakaro, 
besiplečiančio „skliaute / drumsto vandens ratilais“, metaforika („Senkapiuose“ $[4,56]$ ). Pagal G. Bachelard’o koncepciją, taip atspindimas kūrejjo pasąmonèje gyvas ir iškylantis simbolinis mirties prisiminimas, mirties materija, poetinèje vandens refleksijoje iteisinanti šešélio viešpatija ir groži paverčianti liūdesiu $[1,170]$.

Upė Liūnès Sutemos poezijoje yra žmogiškos būties, kraujo analogas. Tradiciškai šios vandens formos reprezentacija poezijoje siejama su judesio - statikos binarine opozicija. Liūnès Sutemos lyrikoje upès įvaizdis nèra dažnas; jis iškyla kaip dvasinio sąstingio antitezè, egzistencinių pokyčių ženklas, atveriantis prigimtinị universumą kaip turintị išskirtinę prasmę svajotojo gyvenime.

Nebera nieko svetimo, miestas, kurio neapkenčiau, dideja,

kabindamasis $i$ skliautus, ir plečiasi, užaugdamas balotus, žmoniu nepaliestus laukus, tiltais peršokdamas upes ir mano kraujuje isimete tas pats, bevardžio miesto atkaklus troškimas, dar ir dar gyvent.

Nebera nieko svetimo -, ir niekad dar nebuvo manyje

tokia gaji, tokia saugi gimtoji žemé.

(„Nebèra nieko svetimo“ $[4,35]$ )

Kūrinio semantinèje plotmèje realizuojama augimo, plètimosi, didèjimo, tekéjimo (upè, kraujas) paradigma, ženklinanti vidini judesį. Eilèraštyje „Prieplaukoj švilpiant laivams“ judesị implikuoja ir metaforinis upès analogas - traukinys ir rašantis brolis: „Prieplaukoj švilpiant laivams, / brolis išgirsta praskubant traukinį, / pro mažą stoti, ir rašo - / apie savo vaikystę rašo, / didelèm, lygiom raidèm" $[4,36]$.

Kraujas - būdingas Liūnès Sutemos poezijos vaizdinys, ịprasminamas kaip aktyvi, ,judanti“, galinga gamtos stichija; tai dažniau ne narsus kraujas, o mirties ženklas, pribloškiantis savo iškalbingu nebylumu. Kraujo puta - dažna Liūnès Sutemos lyrikos semantema, plečianti dramatišką tragedijos diskursą. Poetės lyrikoje ja metaforizuojama išdavystès situacija, turinti provaizdžių senuosiuose lietuvių mituose:

Ant ežerų ir upiu,

kanalų ir fontanu dubeniuose,

liūliuodama žydi kraujo puta-

Ar galima rašyti ja? <...>

Argi begalima rašyti krauju,

kai auga kiekviename Drebule,

išdavusi Žilvina -

ir jo nebera.

$($,Kraujas“ $[4,59])$

Skirtingai nei Liūnès Sutemos, A. Ivaskos poezijoje kraujas - asmeninio tapatumo ženklas ir horizontalè, susiejanti genties istoriją, skirtingų šimtmečių ir epochų realijas. Jam būdinga moteriškojo vertybinio prado dominantè: 
Mano kraujas niūrus, nes Kuršo karaliai,

klejodami

mojuoja kumščiais.

Mano kraujas švelnus,

nes lengvomis vyžomis

lybiu moterys

ranka už rankos vaikšto.

$$
\text { („Sentèviai“ }[2,44] \text { ) }
$$

Su mirties lauku Liūnès Sutemos ir A. Ivaskos poezijoje susiejamas ir polaidis, vandens plūsmas - stichinè jèga, galingiausia pasaulyje, kuriai visiškai paklūsta ir žmogus. Liūnès Sutemos eilèraštyje „Dienoraštis“ polaidis, simbolinis pasaulinis tvanas, išmuša žemès pagrindą iš po kojų, priverčia trauktis kitur, iškeliauti, patirti chaoso, pasimetimo, nežinomybès jausmą; pasak G. Bachelard’o, „mirtis yra kelioné, o kelionė yra mirtis“ $[1,187]$. Viską praradusiam svajotojui belieka tik balsiai skaityti „Lunatiko Kelionių Užrašus“ [2, 44] - taigi toliau tęsiamas sąmonès ir pasąmonès dialogas - skausmingų prisiminimų, dramatiškų potyrių ir nerealizuotų svajonių sublimacija.

\section{IDENTIFIKACIJOS PAIEŠKOS}

Vienas ryškiausių abiejų poečių pasaulèvaizdi siejančių aspektų - gilus vienatvės pojūtis, ryškejjantis beveik visuose jų eilèraščiuose. Iš čia - ir moderniajai lyrikai būdingas poetinio „aš“ skilimas, pasak R. Šilbajorio, reiškiamas ištisa įvaizdžių - antrininkų - grupe [4, 166]: veidrodžio, šukès, paukščio, šakos, taip pat vandens - rasos lašo, ledo, šerkšno, ašaros. Tai viena būdingiausių kūrèjų poetikos priemonių. Ir Liūnès Sutemos, ir A. Ivaskos identifikacijos paieškų procese itin svarbus dėmuo - vanduo. Jis ženklina lemtingą būties ribą, kai sklaidosi realybès iliuzijos, ar atspindžius, kuriuose keičiasi lyrinio subjekto savybès. Liūnès Sutemos poezijoje vidinė tokių išgyvenimų įtampa stiprinama pusnių, ledèjimo metaforomis („Sirpsta naktim pusnyse / spalgenu uogos, ir lededami noksta sakai“ ( Medžioklès metas“, [4, 55]); A. Ivaskos tai - „pumpuruojantis ašaru medis“, „Ariadnès siūlas snieguose“, tęsiantys vienišumo pojūčių raišką („Pūgoje“). Liūnès Sutemos eilèraščiuose sąmonès nuskaidrèjimas, grị̌imas tarsi ị tikrąji savo individualumą reflektuojamas kaip to, kas nereikalinga, išskalavimas, potekstejje brěžiant analogiją su jūra, ežeru:

Sunkius, nereikalingus daiktus,

išnešiotus savy,

išskalavo pasąmone

i saulètą vasaros dieną, -

kaip ežeras išskalauja

negyvas žuvis, žoles, šaknis,

ir kartais kūna žmogaus.

Dabar viska turiu prieš save

(viska, kuomi buvau tikra),

dabar ir vél esu laisva,

ir galiu abejoti.

(„Išskalauti daiktai“ $[4,57]$ ) 
Išsivadavimas iš supančių išorès gniaužtų jos poezijoje reflektuojamas kaip grịžimas prie savojo asmenybės branduolio, kaip tikrojo identiteto atradimas. Toks ėjimas ị tikrąją - laisvą - save ryškus ir Astridos Ivaskos lyrikoje:

Tarp nebūties ir atgimimo laisva,

laisva tarp kalnu ir jüros,

vaisiu laikydama saujoj,

lipnų nuo sulčių.

Veidą atsukus saulèlydžiui,

veidą atsukus aušrai,

gali pagaliau suprasti:

esi viena lyg našlaité

Lietaus karaliaus šaly.

(„Vienatvë“ $[2,42])$

Sultys, sula (vandens analogas), dvasinị atgimimą ženklinanti sema, poečių lyrikoje susieja mikro- ir makropasaulius, pabréžia būdingiausią jų dvasinès identifikacijos formą - pasiaukojančią seserystę. Iškeliama joms svarbiausioji - bendruomeniškumo sema „mes“, ryškèja sąsajos su J. Degutytès poezijos Antigone, kuriai būdingas beatodairiškas rūpinimasis artimojo ir tautinès bendruomenès likimu, esmingiausia būties pozicija. Ir A. Ivaskos, ir Liūnès Sutemos moteris yra laisva rinktis, laisva drąsiai ir ryžtingai veikti, bet jai priešinga galia - stipresnè, palaužianti, parklupdanti aplinkinius, ir ji lieka vieniša. Todèl svajotojo sąmonėje ryški dvasinès vienatvės gaida, stiprẻja troškulio, kaip neišsipildžiusių vilčių, motyvas. Eilèraštyje „Dviejų brolių sesuo...“ Liūnės Sutemos lyrinis „aš“ lipdo ąsotị laukiamam broliui pagirdyti pavasario sula, bet nepasiekia savo tauraus tikslo:

Dvieju broliu sesuo

niūniuodama lipdè iš molio ąsotị

pavasario atvertam beržui,

rudeniu apsunkusiam vynuogynui

ir trečiajam broliui,

tebelaukiamam,

Pasaku Joneliui.

Dvieju broliu sesuo

ilgesiu išdegino molio ąsoti,

žaliu kartèliu išpaišè raštus

ir trokšta viduvasarị viena,

sulos skoni užmiršusi,

vynuogynu neišauginusi,

trečiojo brolio nesulaukusi,

ir skauda saujoj įdegusi

tuščio asočio ąsa -

(„Dviejų brolių sesuo“ $[4,65]$ )

Pasiaukojančios sesers motyvas glaudžiai susijęs su vandens lauku - atsigèrimo / pagirdymo situacija, upès tekejimu, skendimu Liūnès Sutemos kūryboje; kitame ciklo eilëraštyje sesuo užšąla ežere "lyg gruodyje upe“, "po ledu suskilęs ąsotis, / pašiurpę žuvys“ „ir trečiojo brolio šešèlis, / suledejęs tarp vandens žoliu - / suledejjęs kartu su jomis“; sesers 
paralelė - žemé, padengta ledynų $[4,70]$. Taip metaforizuojama baltų moterị amžinai lydinti ir jai lemta netektis, prarasties gèla, būdingiausia dramatiška likimo situacija - netekus savo pasaulio pagrindų, stovèti tuščiomis saujomis. A. Ivaskos lyrikos moteris atsiveria kaip visatoje stipriausias traukos polius - mylinti, globianti, priglaudžianti, bet vis dèlto nugalima jèga. Todèl jos tapatybè reiškiama vandens laukui artimomis užutekio (globa), kriauklès (dvasinè savisauga), kranto (nugalima jūros) metaforomis:

Esu užutekis, į kurị plūsta upé,

kriauklè, kurion banga sugūra,

krantas esu, kurị užlieja potvynis, -

ir mano smèlio pilys tyloj toj grūvi.

(„Esu užutèkis“ $[2,50])$

Atsiveria baltų kultūros moterims būdingas artimumas gamtai, archetipinè baltų moters savastis. Ryškiausia jos manifestacija Liūnès Sutemos kūryboje - lyrinio „aš“ susiliejimas su vandens pasauliu, panirimas i jị:

Jei paleisi mane, išslysiu naktin -

pasinersiu, lyg tvenkinin -

ir leisiu žuvim pelekais savo plaukus šukuot,

ir leisiu vandens vijokliams

dali savęs atmatuot,

kad tvanku vidudieni

ibridę vaikai

turèty ant ko atsistot,

kad nepanerty -

mano veidas bus kampuotas,

apsamanojęs akmuo -

ir motinoms bus ramu,

ir motinos nebijos $-<\ldots>$

$$
\text { („Akmuo“ }[4,99] \text { ) }
$$

Iš tolimos archajinès praeities poečių lyrikoje - ir būrimo, raganavimo motyvas, kaip siekis kurti ir harmonizuoti, skaistinti pasauli, simboliškai pradedamas ritualiniu vandens, pirmapradžio elemento, nuliejimo aktu:

Švęstu vandeniu nuliejau tuščia delną,

kad patekètu saule,

kad pražystų rožé,

kad sudiltų delčia jame - <...>

Raganauju -

Saulèj garuoja džiūdamos

žolelès nuo nemigos, širdies diegliu -

žoleles, kad pavirstum vilkolakiu -

žolelès, kad prašvistu aptemę akys,

žolelès, kad aptemtų šviesios akys,

žolelès, žolelès... 
Sesers, raganos, užutekio, kriauklès metaforika Liūnès Sutemos ir A. Ivaskos kūryboje ipprasminama esminè baltų moters atnašavimo pasauliui funkcija; vanduo šiame sakraliame akte išlieka esminiu pasaulèkūros elementu.

Gauta 20161111

Priimta 20161219

\section{Literatūra}

[1] BACHELARD, Gaston. Svajoniu džiaugsmas. Ugnies psichoanalizè. Vanduo ir svajonès. Erdvès poetika. Iš pranc. k. vertė G. Baužytė-Čepinskienè. Vilnius: Vaga, 1993.

[2] IVASKA, Astride; IVASK, Ivar. Skraidantis ežeras. Sudarytojas S. Gaižiūnas. Vilnius, 2007.

[3] COHEN, Jean. Structure du langage poetique. Paris: Seuil, 1966.

[4] LIŪNĖ SUTEMA. Poezijos rinktinè. Vilnius: Vaga, 1992.

[5] Literatūra un kultūra: process, mijiedarbiba, problemas. Četri pamatelementi kultūra: uguns, ūdens, zeme, gaiss. Zinatnisko rakstu krajums. XIII. Daugavpils, 2011.

[6] LŪSE, Dace. Latviešu trimdas literatūra. Lekciju konspekts. Riga, 1994.

[7] STEPUKONIENĖ, Inga. Baltu literatūra XX amžiaus antrojoje puséje. Kaunas, 2007.

INGA STEPUKONIENE

\section{The Motif of Water in the Poetry of Liūnè Sutema and Astrida Ivaska}

Summary

Liūne Sutema and Astrida Ivaska are certainly among the most unique writers in Baltic literature. Experiences in life as well as in historical, political, and cultural situation of the Baltic states, and their attention for Baltic history and culture structured their poetic world-view. Cultural traditions intersect in their poetry. One of the most important symbols in their poetry is water, which has the meaning of the rhythms of the world and human existance. Also it is closely linked to personal self-identification.

The element of water in the poetry of Liūne Sutema and Astrida Ivaska is mostly a symbol of rain, snow, ice, and the lake, which mostly show strong manifestation of life, and fuse reality and illusion, the real and posthumous life on the same plane. In their poetry, Liūne Sutema and Astrida Ivaska focus on internal and external waters: lakes, rivers, and seas. Liūne Sutema writes much about a lake: in her poems it reflects a myth (a sunken lake, Egle the Queen of Grass-snakes, mythologem), creates the feeling of a cluttered world, marks a possible betrayal and a threat, and a model of hostile human relations. The lake and the sea in Astrida Ivaska's poetry show the harmony between a person and nature which covers all bad inner feelings and frustrations. Lake water in her poetry is linked to the memory of the autochthons and old tribes. It evokes the subject's spiritual vitality and awakening power. Water in the poetry of Liūne Sutema and Astrida Ivaska is the symbol of both life and death. In their poems, the individual tries to save his or her own spiritual world and cultural ego, the ethnic memory which was formed by environment, language, and interpersonal relationships. We notice numerous symbols of rain and snow: in the poems they symbolize life protection and revival of the soul. 
Water is also associated with home. Home in the poetry of Liūne Sutema and Astrida Ivaska takes a significant place. Their homes are enveloped in grey clouds and their roofs are wet with rain. This reminds us of Gaston Bachelard who wrote about the symbol of heavy water that symbolizes extraordinary life which ends with an extraordinary death.

The river in the poetry of Liūne Sutema and Astrida Ivaska is a symbol of human existence and blood. Traditionally this type of water symbolizes the binary opposition of motion/static. The poetry of these two writers is similar due to their quest for their self-identification: in their poetry, we feel an altruistic, self-sacrificing, and unselfish woman. A significant feature of Liūne Sutema's poetry is the motive of sisterhood, which is mostly associated with water. She writes about situations in which a human receives or is given water, or is drowning. In these poems, the destiny of the Baltic woman is mostly that of loss, she feels the pain of deaths. Having lost the foundation of her world she is left with nothing in her hands. Astrida Ivaska shows a strong woman as the centre of the universe whose power is nonetheless vincible. Her identity is expressed through such metaphors as lagoons or the coast. Water remains a significant factor that links these two Baltic poets.

Keywords: poetry of Liūné Sutema, poetry of Astrida Ivaska, motif of water, poetical reflection 